\title{
Analisis Faktor-Faktor yang Memengaruhi Perolehan Surplus Underwriting pada Asuransi Jiwa Syariah di Indonesia (Periode 2015-2020)
}

\section{Analysis on Factors Affecting the Underwriting Surplus of Islamic Life Insurance in Indonesia (2015-2020 Period)}

\author{
Amelia Nadiah Wahyu Putri ${ }^{1}$, Jaenal Effendi ${ }^{2}$ \\ ${ }^{1}$ Fakultas Ekonomi dan Manajemen, nstitut Pertanian Bogor, Jalan Raya Dramaga, Bogor 16680, \\ Indonesia, amelnadiah30@gmail.com \\ ${ }^{2}$ Fakultas Ekonomi dan Manajemen, Institut Pertanian Bogor, Jalan Raya Dramaga, Bogor 16680, \\ Indonesia,jaenfendi@gmail.com
}

\begin{abstract}
In Islamic insurance, if at the end of the period there is a surplus from the substraction result between total insurance income in the tabarru' fund and insurance expenses, the surplus will be called as underwriting surplus. A good Islamic insurance company can be seen when the company succeeds in obtaining an underwriting surplus, because it is a proof when the company has managed the participant funds well. The underwriting surplus can be used as a reserve fund when an underwriting deficit occurs or when insurance expenses exceed insurance income, thereby it can improve the public interest in Islamic insurance. Therefore, this study aims to analyze the development of the underwriting surplus in Islamic life insurance in Indonesia and the factors that influence it by using panel data regression method. The estimation results using the REM model show that the variables of total assets and GDP have a positive and significant effect. Meanwhile, the contribution allowance, claim allowance, and inflation variables have a negative and significant effect.
\end{abstract}

Keywords: Islamic life insurance, panel data regression, underwriting surplus.

\begin{abstract}
Abstrak. Pada asuransi syariah, jika pada akhir periode terjadi selisih lebih dari total pendapatan asuransi ke dalam dana tabarru' dikurang beban asuransi yang dikeluarkan, maka akan terdapat surplus underwriting. Suatu perusahaan asuransi syariah yang baik dapat dilihat ketika perusahaan tersebut berhasil memperoleh surplus underwriting, karena perolehan tersebut adalah suatu bukti ketika perusahaan berhasil mengelola dana peserta dengan baik. Surplus underwriting dapat digunakan sebagai cadangan ketika terjadi defisit underwriting atau ketika beban asuransi melebihi pendapatan asuransi, sehingga dapat meningkatkan minat masyarakat untuk berasuransi syariah. Oleh karena itu, penelitian ini bertujuan untuk menganalisis perkembangan surplus underwriting pada asuransi jiwa syariah di Indonesia dan faktor-faktor yang memengaruhinya dengan metode regresi data panel. Hasil estimasi dengan model REM menunjukkan bahwa variabel total aset dan PDB berpengaruh secara positif dan signifikan. Sementara itu, variabel penyisihan kontribusi, penyisihan klaim, dan inflasi berpengaruh secara negatif dan signifikan.
\end{abstract}

Kata kunci: Asuransi jiwa syariah, regresi data panel, surplus underwriting.

\section{PENDAHULUAN}

\section{Latar Belakang}

Tiap aktivitas sehari-hari, banyak risiko yang sangat mungkin terjadi kepada kita, seperti kerugian, kerusakan, kehilangan, bahkan kematian. Hal-hal negatif tersebut sudah pasti akan memiliki dampak yang negatif pula kepada kehidupan kita. Namun, seringkali upaya yang dilakukan kurang memadai untuk mengatasi risiko tersebut, padahal Allah telah memerintahkan manusia untuk mempersiapkan hari esok sebagaimana tertuang pada surah Al-Hasyr ayat 18: "Hai orang-orang yang beriman! Bertaqwalah kepada Allah dan ingatlah untuk memerhatikan apa yang dilakukan di masa depan, dan bertaqwalah kepada Allah. Allah Maha Mengetahui apa yang kamu lakukan". 
Risiko-risiko yang akan terjadi kepada kita di masa depan, salah satunya dapat diminimalisir melalui asuransi syariah (Ramdhani et al., 2019). Menurut Karim (2016), setiap manusia pasti akan mengalami musibah, baik yang memiliki asuransi maupun yang tidak. Namun, bagi orang yang memiliki asuransi ia akan menjadi lebih tenang karena ada asuransi yang akan membantunya. Selain itu, Malik (2011) menyatakan bahwa asuransi memiliki peran sebagai lembaga perantara keuangan dengan cakupan yang luas. Asuransi tak hanya mampu mengelola risiko masyarakat dengan memberikan perlindungan dari dampak kerugian yang dialami, tetapi juga mampu menyalurkan dana dari masyarakat untuk diinvestasikan ke berbagai sektor dalam jangka panjang, sehingga mampu meningkatkan perekonomian nasional.

Industri asuransi di Indonesia dimulai dengan adanya regulasi dari pemerintah mengenai perasuransian, yaitu Undang-Undang Nomor 2 Tahun 1992 tentang Perasuransian yang menyatakan bahwa terdapat tiga jenis asuransi, yaitu asuransi jiwa, asuransi umum, dan reasuransi. Pada tahun 1994, berdiri perusahaan asuransi syariah di Indonesia yang bernama PT Syarikat Takaful Indonesia (STI). Sejak saat itu, perkembangan industri asuransi syariah di Indonesia terus mengalami perkembangan. Hal ini didukung dengan data dari World Population Review di tahun 2020 yang menyatakan bahwa Indonesia merupakan negara yang memiliki penduduk Muslim paling besar di dunia dengan proporsi masyarakat Muslim sebesar 87.2\% dari keseluruhan penduduk yang berjumlah 273.5 juta jiwa.

Otoritas Jasa Keuangan (2020) mengungkapkan bahwa market share asuransi syariah terhadap asuransi konvensional pada akhir 2020 mencapai 6\%, tidak jauh berbeda dengan pangsa pasar perbankan syariah terhadap perbankan konvensional yang mencapai 6.5\%. Secara keseluruhan, market share industri asuransi syariah di Indonesia terus mengalami peningkatan dengan market share terbesar didominasi oleh asuransi jiwa syariah. Selain itu, dominasi asuransi jiwa syariah juga dapat dilihat pada perkembangan aset produktif asuransi syariah yang ditunjukkan oleh Tabel 1.

Tabel 1 Perkembangan aset produktif asuransi syariah di Indonesia tahun 2015 sampai 2020 (dalam miliar rupiah)

\begin{tabular}{lcccccc}
\hline & $\mathbf{2 0 1 5}$ & $\mathbf{2 0 1 6}$ & $\mathbf{2 0 1 7}$ & $\mathbf{2 0 1 8}$ & $\mathbf{2 0 1 9}$ & $\mathbf{2 0 2 0}$ \\
\hline Asuransi jiwa syariah & 21,614 & 24,565 & 30,417 & 31,882 & 34,327 & 36,317 \\
Asuransi umum syariah & 3,786 & 3,160 & 3,677 & 3,783 & 4,031 & 6,019 \\
Reasuransi syariah & 1,119 & 1,081 & 1,216 & 1,305 & 1,488 & 2,109 \\
\hline
\end{tabular}

Sumber: OJK, 2019 (diolah).

Perkembangan aset produktif asuransi syariah di Indonesia tahun 2015 sampai 2020 ditunjukkan oleh Tabel 1. Secara keseluruhan, perkembangan aset asuransi syariah di Indonesia selalu meningkat. Kenaikan aset tertinggi terjadi pada perusahaan asuransi jiwa syariah.

Operasional perusahaan asuransi syariah membutuhkan proses underwriting, yaitu tahapan untuk memilih risiko dari calon peserta asuransi. Risiko yang dimaksud berkaitan dengan klaim yang akan menjadi beban asuransi di masa depan. Klaim adalah hak atas peserta asuransi ketika terjadi risiko disesuaikan terhadap akad yang disepakati antara perusahaan asuransi dan peserta asuransi (Huda dan Mustafa, 2009). Oleh karena itu, proses underwriting menjadi penting karena dapat menentukan calon peserta asuransi akan ditolak atau diterima oleh perusahaan asuransi (Sastri et al., 2017). Jumlah perolehan surplus underwriting dari asuransi jiwa syariah di Indonesia ditunjukkan pada Gambar 1. 


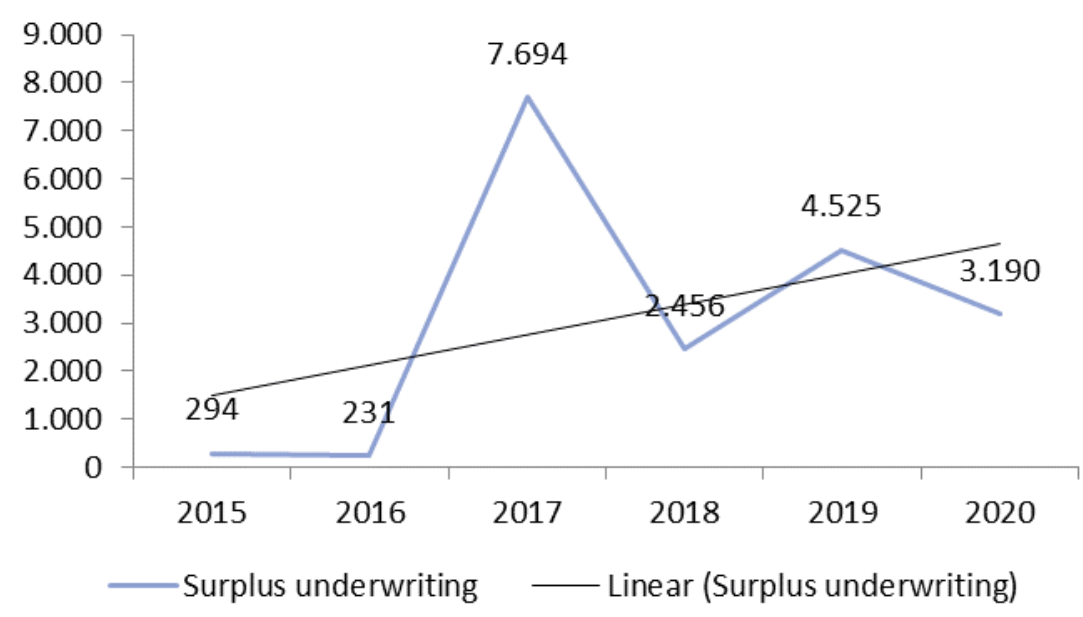

Sumber: OJK, 2019 (diolah).

Gambar 1 Jumlah surplus underwriting asuransi jiwa syariah di Indonesia tahun 2015 sampai 2020 (dalam miliar rupiah)

Pada Gambar 1 terlihat bahwa perkembangan surplus underwriting dari asuransi jiwa syariah di Indonesia tahun 2015 sampai 2020 bergerak secara fluktuatif tiap tahunnya. Namun, tetap memiliki trend yang positif. Meskipun demikian, kenyataannya masih terdapat masalah yang dialami oleh perusahaan asuransi jiwa syariah dalam memperoleh surplus underwriting, yaitu pada unit usaha asuransi jiwa syariah Allianz Life yang memiliki perolehan surplus underwriting dengan trend yang negatif seperti yang terlihat pada Gambar 2 .

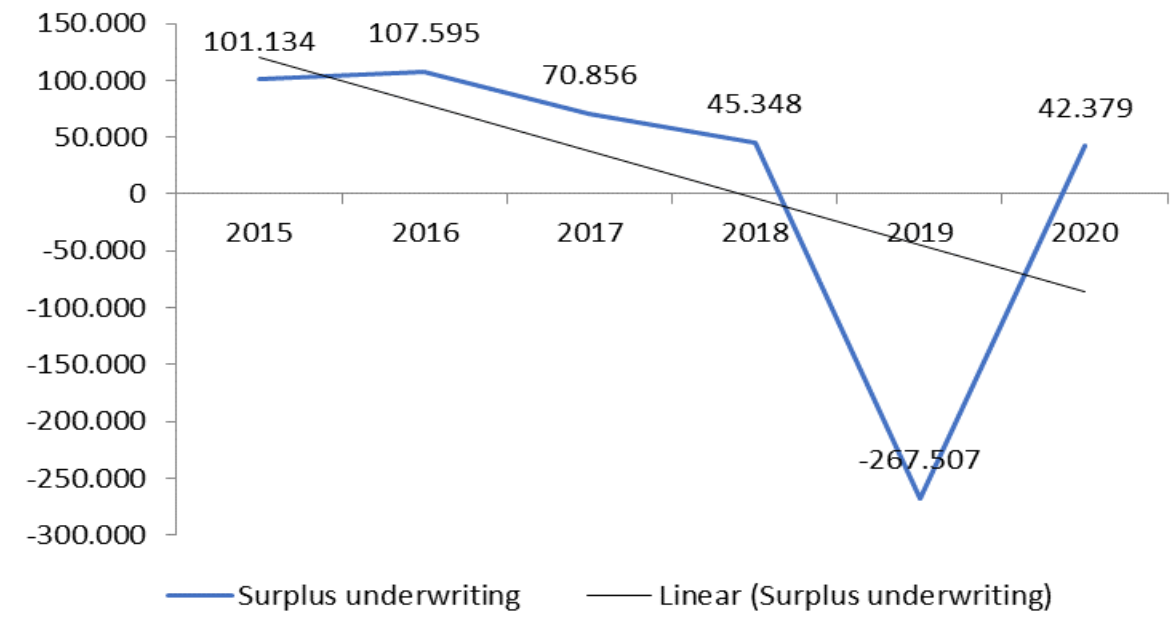

Sumber: Laporan keuangan tahunan unit usaha asuransi jiwa syariah Allianz Life, 2021 (diolah).

Gambar 2 Jumlah surplus underwriting unit usaha asuransi jiwa syariah Allianz Life tahun 2015 sampai 2020 (dalam jutaan rupiah)

Pada Gambar 2 terlihat bahwa perkembangan surplus underwriting dari unit usaha asuransi jiwa syariah Allianz Life tahun 2015 sampai 2020 memiliki trend yang negatif. Bahkan, mengalami defisit underwriting dengan jumlah yang cukup besar pada tahun 2019, yaitu sebesar Rp 267.507 juta. Terjadinya defisit underwriting disebabkan dana tabarru' peserta dikelola dengan kurang baik oleh unit usaha asuransi jiwa syariah tersebut. Hal ini mengindikasikan bahwa terdapat kesalahan dalam kegiatan operasional perusahaan asuransi jiwa syariah dalam mengelola dana peserta (Karim Consulting, 2016). 
Kasus defisit underwriting yang dialami oleh usaha asuransi jiwa syariah Allianz Life pada tahun 2019 membuktikan pentingnya surplus underwriting bagi suatu perusahaan asuransi syariah maupun bagi peserta asuransi syariah. Surplus underwriting yang diperoleh dapat digunakan sebagai cadangan ketika terjadi defisit underwriting atau ketika beban asuransi melebihi pendapatan asuransi, sehingga gagal bayar tidak akan terjadi. Dengan demikian, suatu perusahaan asuransi syariah yang baik dapat dilihat ketika perusahaan tersebut berhasil memperoleh surplus underwriting, karena perolehan tersebut adalah suatu bukti ketika perusahaan berhasil mengelola dana peserta dengan tepat, sehingga dapat menumbuhkan ketertarikan masyarakat dalam berasuransi syariah (Alifianingrum dan Suprayogi, 2018).

\section{TINJAUAN PUSTAKA}

Berdasarkan Undang-Undang Nomor 40 Tahun 2014, asuransi jiwa syariah merupakan upaya mengelola risiko yang disesuaikan pada prinsip syariah dengan menyalurkan pertanggungan atas risiko yang dialami peserta pada waktu dan jumlah yang disesuaikan dengan akad yang telah disetujui. Dalam penggunaan produk asuransi jiwa syariah, terdapat suatu kontrak perlindungan tertulis yang disebut polis. Polis ini berisi kontrak kesepakatan antara perusahaan asuransi jiwa syariah dengan peserta sebagai pemilik polis, di mana perusahaan memiliki kewajiban untuk memberikan dana kepada ahli waris apabila peserta yang bersangkutan mengalami kematian.

Underwriting adalah tahapan untuk memilih risiko dari calon peserta asuransi sehingga dapat ditentukan calon peserta asuransi akan ditolak atau diterima oleh perusahaan asuransi. Berdasarkan Peraturan Menteri Keuangan (PMK) Nomor 18 Tahun 2010, surplus underwriting adalah selisih lebih total kontribusi peserta ke dalam dana tabarru' setelah dikurangi klaim, kontribusi reasuransi dan kenaikan cadangan teknis, ditambah kenaikan aset reasuransi dalam satu periode tertentu. Singkatnya, surplus underwriting didapatkan dari pendapatan asuransi dikurangi beban asuransi. Surplus underwriting akan diperoleh oleh perusahaan asuransi ketika hasil pengurangan tersebut bernilai positif, sedangkan defisit underwriting akan diperoleh oleh perusahaan asuransi ketika hasil pengurangan tersebut bernilai negatif.

Berdasarkan penjelasan di atas, dapat diketahui bahwa kontribusi dan hasil investasi merupakan faktor penambah pada pendapatan asuransi, sedangkan klaim menjadi faktor penambah pada beban asuransi. Namun selain itu, terdapat penyisihan kontribusi dan penyisihan klaim yang juga menjadi faktor penambah pada beban asuransi. Menurut Peraturan Menteri Keuangan (PMK) Nomor 10 Tahun 2011, penyisihan kontribusi dan penyisihan klaim adalah bentuk kewajiban perusahaan asuransi jiwa syariah kepada peserta, dengan kata lain penyisihan kontribusi dan penyisihan klaim menjadi beban asuransi sehingga penyisihan kontribusi dan penyisihan klaim akan berpengaruh negatif terhadap surplus underwriting dana tabarru'.

Untuk menunjang kegiatan operasional perusahaan, diperlukan suatu variabel yang menunjukkan total harta perusahaan yang disebut total aset. Total aset pada dasarnya merupakan suatu tolak ukur dari kinerja suatu perusahaan, artinya semakin besar total aset perusahaan, maka semakin besar sumber daya dan kapabilitas perusahaan tersebut untuk mencapai tujuan dan bertahan dalam pasar (Prasetyantoko dan Parmono, 2015). Ketika total aset tinggi, perusahaan menjadi lebih kuat, mendapatkan lebih banyak peserta, dan memiliki pengelolaan keuangan yang baik, dengan demikian dapat menyebabkan perolehan surplus underwriting dana tabarru' (Guendouz dan Ouassaf, 2018).

Sementara itu, dua variabel makroekonomi dipandang memengaruhi perolehan surplus underwriting, yaitu PDB dan inflasi. PDB dapat menjadi salah satu ukuran peningkatan ekonomi karena melalui PDB ini dapat diketahui gambaran tentang kondisi perekonomian di suatu negara dalam kurun waktu tertentu (Cahyani, 2018). Ketika PDB mengalami peningkatan, akibatnya minat masyarakat untuk berasuransi syariah juga akan meningkat, singkatnya PDB memiliki hubungan yang positif dengan perolehan surplus underwriting (Zein dan Shofawati, 2017). Sedangkan inflasi adalah peningkatan 
seluruh tingkat harga yang berlangsung secara terus-menerus, meluas dan menyebabkan kenaikan pada barang lainnya (Mankiw, 2005). Inflasi yang besar juga dapat memengaruhi industri asuransi syariah, di mana dapat mengarah pada minat masyarakat untuk berasuransi syariah yang menurun, karena masyarakat lebih berfokus untuk melakukan spending pada kebutuhan pokoknya, sehingga perolehan surplus underwriting juga akan menurun (Karl et al., 2010).

Chugh et al. (1987) meneliti mengenai faktor yang memengaruhi underwriting profitability pada asuransi properti dan kewajiban dan menghasilkan bahwa market share dan total aset secara signifikan tidak memengaruhi underwriting profitability, sedangkan PDB secara positif dan signifikan memengaruhi underwriting profitability. Damayanti dan Mawardi (2016) meneliti tentang faktor yang memengaruhi surplus underwriting pada asuransi umum syariah di Indonesia dan menghasilkan bahwa kontribusi secara positif memengaruhi surplus underwriting, hasil investasi secara signifikan tidak memengaruhi surplus underwriting, dan klaim secara negatif memengaruhi surplus underwriting. Alifianingrum dan Suprayogi (2018) meneliti tentang faktor yang memengaruhi surplus underwriting dana tabarru' pada perusahaan asuransi jiwa syariah di Indonesia dan menghasilkan bahwa kontribusi neto dan hasil investasi secara positif dan signifikan memengaruhi surplus underwriting, sedangkan beban klaim secara negatif dan signifikan memengaruhi surplus underwriting.

Berdasarkan penelitian terdahulu di atas, terdapat beberapa perbedaan antara penelitian ini dengan penelitian sebelumnya. Pertama, penelitian ini menggunakan sampel penelitian dengan jumlah terbanyak, yaitu 17 sampel penelitian. Kedua, penelitian ini memiliki periode penelitian yang paling baru, yaitu sampai tahun 2020. Ketiga, penelitian ini menggunakan variabel independen yang berasal dari faktor internal dan faktor eksternal perusahaan asuransi jiwa syariah di Indonesia, yaitu penyisihan kontribusi, penyisihan klaim, total aset, PDB, dan inflasi.

Hipotesis penelitian pada penelitian ini, yaitu:

1. Penyisihan kontribusi memengaruhi perolehan surplus underwriting asuransi jiwa syariah di Indonesia secara negatif dan signifikan.

2. Penyisihan klaim memengaruhi perolehan surplus underwriting asuransi jiwa syariah di Indonesia secara negatif dan signifikan.

3. Total aset memengaruhi perolehan surplus underwriting asuransi jiwa syariah di Indonesia secara positif dan signifikan.

4. PDB memengaruhi perolehan surplus underwriting asuransi jiwa syariah di Indonesia secara positif dan signifikan.

5. Inflasi memengaruhi perolehan surplus underwriting asuransi jiwa syariah di Indonesia secara negatif dan signifikan.

\section{METODE}

Penelitian ini menggunakan data sekunder dalam bentuk data panel yang merupakan perpaduan dari data cross section 17 perusahaan dan unit asuransi jiwa syariah di Indonesia dan data time series berupa laporan keuangan kuartal tahun 2015 sampai tahun 2020. Data didapatkan dari situs tiap perusahaan asuransi jiwa syariah berupa Laporan Keuangan Tahunan dari Badan Pusat Statistik (BPS) dan dari Bank Indonesia.

Teknik purposive sampling digunakan pada penelitian ini untuk menarik sampel penelitian, di mana sampel yang dipilih sesuai dengan kriteria tertentu. Kriteria tersebut yaitu perusahaan asuransi jiwa syariah yang tercatat pada statistik perasuransian syariah OJK dan telah mengeluarkan laporan keuangan tahunan setiap periodenya. Terdapat 5 perusahaan dan 20 unit asuransi jiwa syariah yang terdaftar sejak tahun 2014. Namun, setelah dilakukan pengecekan laporan keuangan tahunan melalui website masing-masing perusahaan, didapatkan bahwa jumlah perusahaan yang memenuhi kriteria tersebut sebanyak 4 perusahaan dan 13 unit asuransi jiwa syariah di Indonesia. 
Tabel 2 Daftar perusahaan asuransi jiwa syariah di Indonesia

\begin{tabular}{cl}
\hline No & Nama Perusahaan Asuransi Jiwa Full Syariah \\
\hline 1 & PT Asuransi Takaful Keluarga \\
2 & PT Asuransi Jiwa Syariah Al-Amin \\
3 & PT Asuransi Jiwa Syariah Amanahjiwa Giri Artha \\
4 & PT Asuransi Jiwa Syariah Jasa Mitra Abadi \\
\hline
\end{tabular}

Sumber: OJK, 2019 (diolah).

Tabel 3 Daftar perusahaan asuransi jiwa unit usaha syariah di Indonesia

\begin{tabular}{cl}
\hline No & Nama Perusahaan Asuransi Jiwa Unit Usaha Syariah \\
\hline 1 & PT AIA Financial \\
2 & PT Asuransi Allianz Life Indonesia \\
3 & PT Asuransi BRI Life \\
4 & PT Asuransi Jiwa Central Asia Raya \\
5 & PT Asuransi Jiwa Manulife Indonesia \\
6 & PT Asuransi Jiwa Sinar Mas MSIG \\
7 & PT Avrist Assurance \\
8 & PT BNI Life Insurance \\
9 & PT Panin Daichi Life \\
10 & PT Prudential Life Assurance \\
11 & PT Sun Life Financial Indonesia \\
12 & PT Tokio Marine Life Insurance Indonesia \\
13 & PT Chubb Life Insurance \\
\hline
\end{tabular}

Sumber: OJK, 2029 (diolah).

Penelitian ini memakai dua metode analisis, yaitu analisis deskriptif untuk mengetahui perkembangan dari variabel dependen dan variabel independen yang digunakan pada penelitian, dan analisis kuantitatif dalam menganalisis faktor apa saja yang memengaruhi perolehan surplus underwriting pada perusahaan dan unit usaha asuransi jiwa syariah di Indonesia. Pengolahan data pada penelitian ini menggunakan dua perangkat lunak, yaitu Microsoft Excel 2010 untuk analisis deskriptif dan Stata 13 untuk analisis kuantitatif.

\section{Regresi Data Panel}

Data panel yang diregresikan disebut model regresi data panel (Gujarati, 2006). Persamaan umum regresi data panel, yaitu:

$$
Y_{i t}=X_{i t} \beta+\varepsilon_{i t}
$$

Keterangan:

$Y_{i t} \quad$ : nilai variabel dependen pada setiap unit individu i pada periode $\mathrm{t}$

$X_{i t} \quad$ : nilai variabel independen yang terdiri atas sejumlah $\mathrm{K}$ variabel.

$\beta \quad$ : parameter yang diestimasi

$\varepsilon_{i t} \quad$ : error term

Dengan demikian, persamaan umum pada penelitian ini, sebagai berikut:

$$
Y_{i t}=X_{1 i t} \beta_{1}+X_{2 i t} \beta_{2}+X_{3 i t} \beta_{3}+X_{4 i t} \beta_{4}+X_{5 i t} \beta_{5}+\varepsilon_{i t}
$$

Keterangan:

$Y_{i t} \quad$ : Nilai surplus underwriting untuk setiap unit individu i pada periode $\mathrm{t}$

$X_{1 i t} \quad$ : nilai variabel penyisihan kontribusi yang terdiri atas sejumlah $\mathrm{K}$ variabel

$X_{2 i t} \quad$ : nilai variabel penyisihan klaim yang terdiri atas sejumlah $\mathrm{K}$ variabel

$X_{3 i t} \quad$ : nilai variabel total aset yang terdiri atas sejumlah $\mathrm{K}$ variabel

$X_{4 i t} \quad$ : nilai variabel PDB yang terdiri atas sejumlah $\mathrm{K}$ variabel

190 
$X_{5 i t} \quad$ : nilai variabel inflasi yang terdiri atas sejumlah $\mathrm{K}$ variabel

$\beta_{1} \quad$ : parameter penyisihan kontribusi yang diestimasi

$\beta_{2} \quad$ : parameter penyisihan klaim yang diestimasi

$\beta_{3} \quad$ : parameter total aset yang diestimasi

$\beta_{3} \quad$ : parameter PDB yang diestimasi

$\beta_{3} \quad$ : parameter inflasi yang diestimasi

$\varepsilon_{i t} \quad$ : error term

Data panel dapat diestimasi dengan tiga cara, yaitu Pooled Least Square (PLS), Fixed Effect Model (FEM), dan Random Effect Model (REM). Pengujian kesesuaian model terbaik pada data panel diperlukan untuk menentukan model yang sesuai untuk mengolah data panel. Uji Chow dilakukan untuk memilih model yang paling baik antara model PLS atau FEM, uji Hausman dilakukan untuk memilih model yang paling baik antara FEM atau REM, sedangkan uji LM dilakukan untuk memilih model yang paling baik antara REM atau model PLS.

Setelah model terbaik telah ditemukan, dilakukan uji asumsi klasik supaya dapat dihasilkan model yang mencakup syarat Best Linear Unbiased Estimator (BLUE). Uji asumsi klasik yang dilakukan adalah uji multikolinearitas, uji heteroskedastisitas dan uji autokorelasi. Selanjutnya dilakukan pengujian statistik dan hipotesis dengan menggunakan T-Test. Pengaruh antara variabel X secara parsial pada variabel $\mathrm{Y}$ bisa ditemukan dengan T-Test. Jika nilai probabilitas < taraf nyata, maka variabel X secara signifikan memegaruhi variabel Y.

\section{HASIL DAN PEMBAHASAN}

\section{Perkembangan Surplus Underwriting Asuransi Jiwa Syariah di Indonesia}

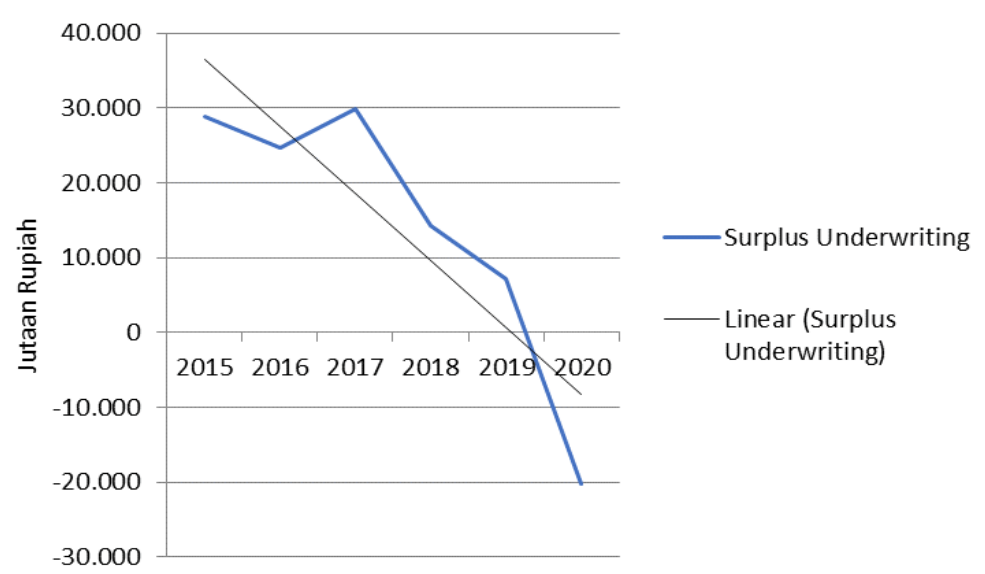

Sumber: Laporan keuangan perusahaan dan unit usaha asuransi jiwa syariah tahun 2015 sampai tahun 2020 (diolah)

Gambar 3 Rata-rata pertumbuhan surplus underwriting perusahaan dan unit usaha asuransi jiwa syariah di Indonesia tahun 2015 sampai tahun 2020

Gambar 3 menunjukkan rata-rata perkembangan surplus underwriting perusahaan asuransi jiwa syariah di Indonesia tahun 2015 sampai tahun 2020. Surplus underwriting adalah selisih lebih total pendapatan asuransi pada dana tabarru' sesudah dikurang seluruh beban asuransi pada suatu periode. Surplus underwriting akan diperoleh oleh perusahaan asuransi ketika hasil pengurangan tersebut bernilai positif, sedangkan defisit underwriting akan didapatkan oleh perusahaan asuransi ketika hasil pengurangan tersebut bernilai negatif. Berdasarkan Gambar 3 dapat dilihat bahwa rata-rata surplus underwriting dari seluruh sampel di penelitian ini bergerak secara fluktuatif dengan trend yang selalu 
menurun. Rata-rata surplus underwriting tertinggi terjadi di 2017 sebesar Rp 29.951 juta, sedangkan rata-rata surplus underwriting terendah terjadi di 2020 sebesar minus Rp 20.276 juta.

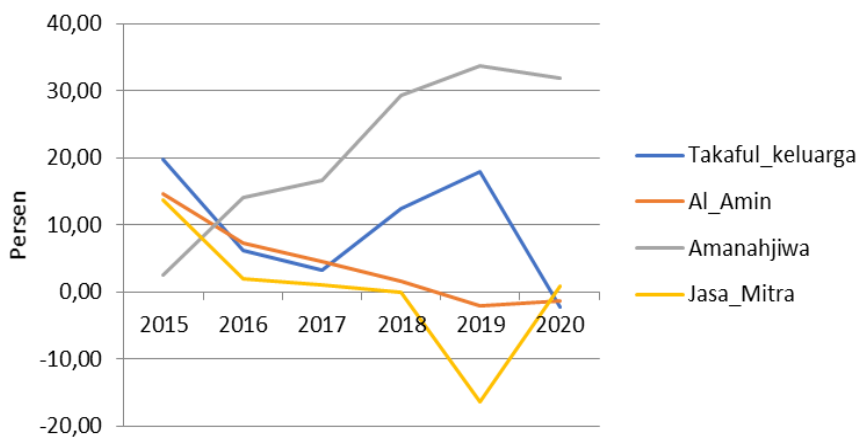

Sumber: Laporan keuangan perusahaan asuransi jiwa syariah tahun 2015 sampai tahun 2020 (diolah).

Gambar 4 Rasio surplus underwriting terhadap kontribusi peserta perusahaan asuransi jiwa syariah di Indonesia tahun 2015 sampai tahun 2020

Gambar 4 menunjukkan rasio surplus underwriting terhadap kontribusi peserta 4 perusahaan asuransi jiwa syariah di Indonesia tahun 2015 sampai tahun 2020. Berdasarkan Gambar 4, hanya Amanahjiwa Giri Artha yang memiliki rasio surplus underwriting terhadap kontribusi peserta dengan trend yang terus meningkat dibandingkan dengan ketiga perusahaan asuransi jiwa syariah lainnya. Takaful Keluarga, Al-Amin dan Jasa Mitra memiliki rasio surplus underwriting terhadap kontribusi peserta dengan trend yang terus menurun.

Takaful Keluarga memiliki rasio surplus underwriting terhadap kontribusi peserta tertinggi pada 2015 sebesar $19.84 \%$ dan memiliki rasio surplus underwriting terhadap kontribusi peserta terendah pada 2020 sebesar minus $2.18 \%$. Al-Amin memiliki rasio surplus underwriting terhadap kontribusi peserta tertinggi pada 2015 sebesar $13.65 \%$ dan memiliki rasio surplus underwriting terhadap kontribusi peserta terendah pada 2019 sebesar minus 2.08\%. Jasa Mitra memiliki rasio surplus underwriting terhadap kontribusi peserta tertinggi pada 2015 sebesar $19.84 \%$ dan memiliki rasio surplus underwriting terhadap kontribusi peserta terendah pada 2019 sebesar minus $16.30 \%$.

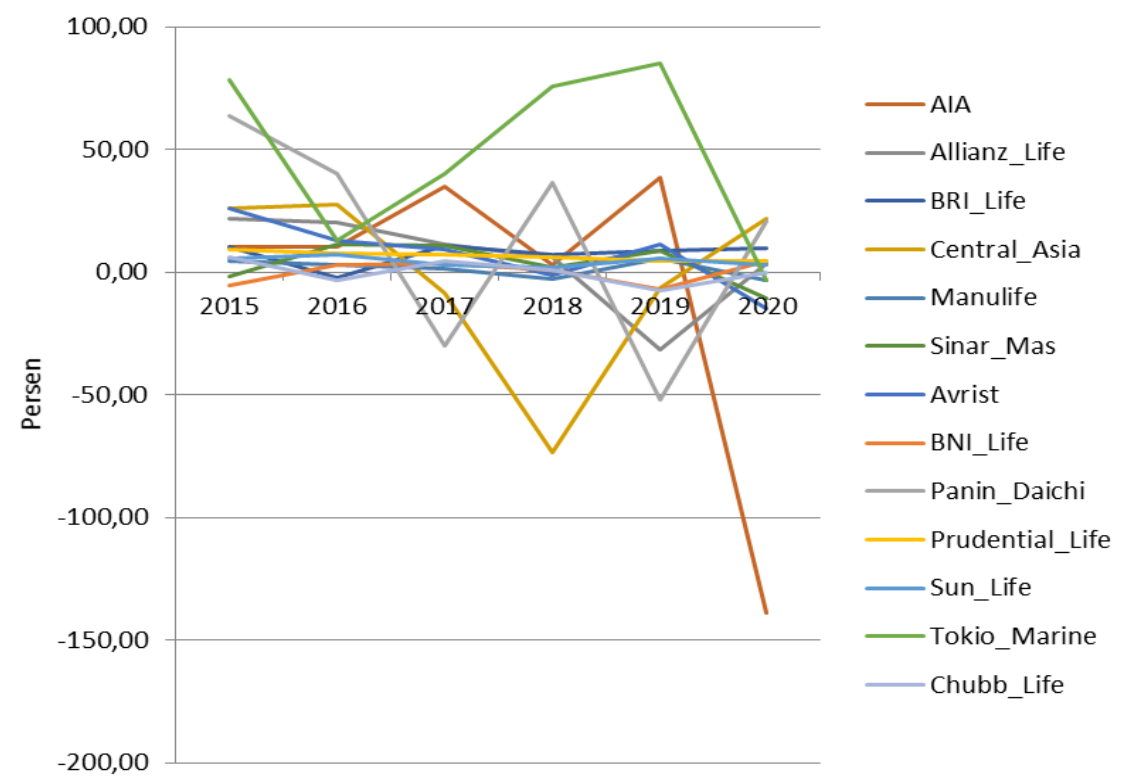

Sumber: Laporan keuangan unit usaha asuransi jiwa syariah tahun 2015 sampai tahun 2020 (diolah).

Gambar 5 Rasio surplus underwriting terhadap kontribusi peserta unit usaha asuransi jiwa syariah di Indonesia tahun 2015 sampai tahun 2020 
Gambar 5 menunjukkan rasio surplus underwriting terhadap kontribusi peserta 13 unit usaha asuransi jiwa syariah di Indonesia tahun 2015 sampai tahun 2020. Pada tahun 2015 sampai tahun 2020, seluruh unit usaha asuransi jiwa syariah memiliki rasio surplus underwriting terhadap kontribusi peserta yang fluktuatif. Berdasarkan Gambar 5, rasio surplus underwriting terhadap kontribusi peserta tertinggi didominasi oleh Tokio Marine pada 2019, 2018, dan 2015 dengan perolehan tertinggi pada 2019 sebesar 84.99\%, lalu didominasi juga oleh Panin Daichi sebesar 63.69\% pada 2015.

Selanjutnya, rasio surplus underwriting terhadap kontribusi peserta terendah didominasi oleh AIA sebesar minus $139.08 \%$ pada 2020 dan didominasi oleh Central Asia sebesar minus $73.67 \%$ pada 2018. Sisanya, 9 unit usaha asuransi jiwa syariah lainnya memiliki rasio surplus underwriting terhadap kontribusi peserta berkisar antara minus 50\% sampai $40 \%$.

\section{Faktor-faktor yang Memengaruhi Perolehan Surplus Underwriting pada Asuransi Jiwa Syariah di Indonesia}

Hasil Uji Chow menunjukkan nilai Prob $>F$ sebesar 0.3622 yang lebih besar dibandingkan taraf nyata a sebesar 5\%, sehingga dapat disimpulkan bahwa pendekatan PLS lebih baik daripada pendekatan FEM. Hasil Uji Hausman menunjukkan nilai Prob>Chi2 sebesar 0.4817 yang lebih besar dibandingkan taraf nyata $\alpha$ sebesar 5\%, sehingga dapat disimpulkan bahwa pendekatan REM lebih baik daripada pendekatan FEM. Hasil uji LM menunjukkan nilai Prob>Chi2 sebesar 0.0001 yang lebih kecil dibandingkan taraf nyata $\alpha$ sebesar 5\%, sehingga dapat disimpulkan bahwa pendekatan REM lebih baik daripada pendekatan PLS. Dengan demikian, berdasarkan hasil Uji Chow, Uji Hausman dan Uji LM yang dilakukan, pendekatan terbaik untuk mengestimasi model pada penelitian ini adalah REM.

Uji multikolinearitas yang dilakukan tidak menunjukkan adanya pelanggaran asumsi multikolinearitas. Sementara itu, uji heteroskedastisitas dan autokorelasi tidak perlu dilakukan karena pada model REM diasumsikan bahwa metode estimasi Generalized Least Square (GLS) dapat mengatasi heteroskedastisitas dan autokorelasi (Ekananda, 2016).

Berdasarkan hasil estimasi melalui model REM, semua variabel independen secara signifikan memengaruhi perolehan surplus underwriting pada asuransi jiwa syariah di Indonesia. Tabel 4 menunjukkan hasil estimasi dari tiap variabel independen pada model.

Tabel 4 Faktor-faktor yang memengaruhi pendapatan dan keuntungan usaha responden setelah pembiayaan

\begin{tabular}{lcccc}
\hline \multicolumn{1}{c}{ Y } & Coefficient & Std. Error & $\mathbf{z}$ & $\mathbf{P}>|\mathbf{z}|$ \\
\hline PenyisihanKontribusi & -0.2702268 & 0.8932583 & -3.29 & $0.001^{*}$ \\
PenyisihanKlaim & -3.193743 & 1.325688 & -2.34 & $0.016^{*}$ \\
TotalAset & 0.0007787 & 0.042185 & 0.18 & $0.035^{*}$ \\
PDB & 0.0048769 & 0.0088825 & 0.53 & $0.007^{*}$ \\
Inflasi & -0.0025911 & 0.0048769 & -0.51 & $0.025^{*}$ \\
\hline
\end{tabular}

Keterangan: *signifikan pada taraf nyata $5 \%$

Didasarkan pada hasil estimasi di atas, maka persamaan model penduga untuk faktor yang memengaruhi perolehan surplus underwriting pada asuransi jiwa syariah di Indonesia adalah sebagai berikut:

Surplus underwriting $=-0.2702268$ penyisihankontribusi -3.193743 penyisihanklaim + 0.0007787 totalaset $+0.0048769 p d b-0.0025911$ inflasi $+\varepsilon$

Koefisien pada variabel penyisihan kontribusi senilai 0.7418955 . Nilai tersebut menunjukkan kontribusi memengaruhi surplus underwriting pada asuransi jiwa syariah di Indonesia secara positif dan signifikan. Peningkatan kontribusi sebesar 1\% akan menyebabkan kenaikan perolehan surplus 
underwriting pada asuransi jiwa syariah di Indonesia sebesar $0.7418955 \%$. Hasil tersebut sesuai dengan Peraturan Menteri Keuangan (PMK) Nomor 10 Tahun 2011 yang menyatakan bahwa penyisihan kontribusi merupakan beban asuransi sehingga akan berpengaruh negatif terhadap surplus underwriting dana tabarru'.

Koefisien pada variabel penyisihan klaim sebesar -0.7914944. Nilai tersebut menunjukkan klaim memengaruhi surplus underwriting pada asuransi jiwa syariah di Indonesia secara negatif dan signifikan. Peningkatan klaim sebesar $1 \%$ akan menyebabkan penurunan perolehan surplus underwriting pada asuransi jiwa syariah di Indonesia sebesar $0.7914944 \%$. Hasil tersebut sesuai dengan Peraturan Menteri Keuangan (PMK) Nomor 10 Tahun 2011 yang menyatakan bahwa penyisihan klaim merupakan beban asuransi sehingga akan berpengaruh negatif terhadap surplus underwriting dana tabarru'.

Koefisien pada variabel total aset sebesar 0.0007787. Nilai tersebut menunjukkan total aset memengaruhi surplus underwriting pada asuransi jiwa syariah di Indonesia secara positif dan signifikan. Peningkatan total aset sebesar 1\% akan menyebabkan kenaikan perolehan surplus underwriting pada asuransi jiwa syariah di Indonesia sebesar $0.0007787 \%$. Hasil tersebut sesuai dengan penelitian dari Guendouz dan Ouassaf (2018) yang menyebutkan bahwa total aset memengaruhi perolehan surplus underwriting pada asuransi jiwa syariah di Indonesia secara positif.

Koefisien pada variabel PDB sebesar 0.0048769. Nilai tersebut menunjukkan PDB memengaruhi surplus underwriting pada asuransi jiwa syariah di Indonesia secara positif dan signifikan. Peningkatan PDB sebesar 1\% akan menyebabkan kenaikan perolehan surplus underwriting pada asuransi jiwa syariah di Indonesia sebesar $0.0048769 \%$. Hasil tersebut sesuai dengan penelitian dari Zein dan Shofawati (2017) yang menyebutkan bahwa PDB memengaruhi perolehan surplus underwriting pada asuransi jiwa syariah di Indonesia secara positif.

Koefisien pada variabel inflasi sebesar -0.0025911. Nilai tersebut menunjukkan inflasi memengaruhi surplus underwriting pada asuransi jiwa syariah di Indonesia secara negatif dan signifikan. Peningkatan inflasi sebesar $1 \%$ akan menyebabkan penurunan perolehan surplus underwriting pada asuransi jiwa syariah di Indonesia sebesar $0.002591 \%$. Hasil tersebut sesuai dengan penelitian dari Karl et al. (2010) yang menyebutkan bahwa inflasi memengaruhi perolehan surplus underwriting pada asuransi jiwa syariah di Indonesia secara negatif.

\section{Implikasi Kebijakan}

Berdasarkan hasil penelitian yang telah dilakukan, perusahaan asuransi jiwa syariah perlu mengevaluasi kinerja perusahaan yang berkaitan dengan pengelolaan dana peserta dengan memerhatikan kelima hal yang menjadi variabel independen pada penelitian, yaitu penyisihan kontribusi, penyisihan klaim, total aset, PDB, dan inflasi. Total aset memengaruhi perolehan surplus underwriting secara positif, sehingga perusahaan asuransi jiwa syariah di Indonesia harus meningkatkan pemasaran produknya agar jumlah peserta yang didapatkan semakin bertambah. Penyisihan kontribusi dan penyisihan klaim memengaruhi perolehan surplus underwriting secara negatif, sehingga perusahaan asuransi jiwa syariah di Indonesia harus melakukan kegiatan underwriting dengan tepat agar tidak timbul risiko-risiko di luar perhitungan.

PDB memengaruhi perolehan surplus underwriting secara positif, sedangkan inflasi memengaruhi perolehan surplus underwriting secara negatif. Artinya, apabila PDB mengalami pengingkatan, maka keinginan masyarakat untuk memiliki asuransi syariah juga mengalami peningkatan, sedangkan apabila inflasi meningkat, maka kecenderungan minat masyarakat untuk berasuransi syariah akan menurun. Dengan demikian, perusahaan asuransi jiwa syariah di Indonesia perlu membuat variasi produk yang dapat tetap menarik minat masyarakat untuk berasuransi syariah dalam kondisi apapun, baik saat PDB meningkat, maupun saat inflasi meningkat. Selain itu, pemerintah Indonesia juga dipandang perlu untuk mengawasi dan menjaga kestabilan perekonomian Indonesia agar tidak 194 
terjadi lonjakan harga kebutuhan primer yang menyebabkan menurunnya keinginan masyarakat dalam berasuransi syariah.

\section{SIMPULAN}

Perusahaan dan unit usaha asuransi jiwa syariah di Indonesia tahun 2015 sampai tahun 2020 memiliki perkembangan surplus underwriting yang bergerak secara fluktuatif dengan trend yang selalu menurun. Hal ini diakibatkan kelima faktor yang memengaruhi perolehan surplus underwriting, yaitu penyisihan kontribusi, penyisihan klaim, total aset, PDB, dan inflasi secara umum bergerak secara fluktuatif pula.

Pengujian variabel pada estimasi faktor-faktor yang memengaruhi perolehan surplus underwriting pada asuransi jiwa syariah di Indonesia dilakukan menggunakan regresi data panel dengan model REM. Secara keseluruhan dapat dikemukakan bahwa keseluruhan variabel secara parsial signifikan pada taraf nyata 5\% memengaruhi perolehan surplus underwriting pada asuransi jiwa syariah di Indonesia. Semua variabel independen, yaitu penyisihan kontribusi, penyisihan klaim, total aset, PDB, dan inflasi mempunyai arah yang sesuai dengan teori. Total aset dan PDB memengaruhi perolehan surplus underwriting pada asuransi jiwa syariah di Indonesia secara positif dan signifikan pada taraf nyata 5\%, sedangkan penyisihan kontribusi, penyisihan klaim, dan inflasi memengaruhi surplus underwriting pada asuransi jiwa syariah di Indonesia secara negatif dan signifikan pada taraf nyata $5 \%$.

\section{DAFTAR PUSTAKA}

Alifianingrum, R. \& Suprayogi, N. (2018). Faktor-faktor yang mempengaruhi surplus underwriting dana tabarru'pada perusahaan asuransi jiwa syariah. Jurnal Ekonomi Syariah Teori dan Terapan, 5(2), 143-157.

Cahyani, Y. (2018). Pengaruh inflasi, suku bunga (BI rate), Produk Domestik Bruto (PDB) terhadap ROA (Studi pada Bank Pembiayaan Rakyat Syariah (BPRS) di Indonesia tahun 2009-2016). Jurnal Ekonomi dan Perbankan Syariah, 5(1), 58-83.

Chugh L., Meador J., \& Chatterjee S. (1987). Determinants of underwriting profitability in the property and liability insurance. The Journal of Insurance Issues and Practices, 10(2), 1-15.

Damayanti, F. E. \& Mawardi, I. (2016). Analisis faktor-faktor yang mempengaruhi surplus underwriting asuransi umum syariah di Indonesia. Jurnal Ekonomi Syariah Teori dan Terapan, 3(12), 989-1005.

[DSN MUI] Dewan Syariah Nasional Majelis Ulama Indonesia. (2001). Fatwa DSN MUI Nomor 21 Tahun 2001 tentang Pedoman Umum Asuransi Syariah [Internet]. [diakses 2020 Agustus 9]. Tersedia pada: http://dsnmui.or.id.

Ekananda, M. (2016). Analisis Ekonometrika Data Panel Edisi 2. Jakarta (ID), Mitra Wacana Media.

Guendouz, A. A., \& Ouassaf, S. (2018). Determinants of saudi takaful insurance companies profitability. Academy of Accounting and Financial Studies Journal, 22(5), 1-24.

Gujarati, D. N. (2006). Ekonometrika Dasar. Jakarta (ID), Erlangga.

Huda \& Mustafa. (2009). Current Issues Lembaga Keuangan Syariah. Jakarta (ID), Prenada Media Grup.

Karim Consulting Indonesia. (2016). Islamic Insurance Outlook 2017 [Internet]. [diakses pada 2021 Januari 27]. Tersedia pada: https://karimconsulting.com/outlook-asuransi-syariah-2017/.

Karl K., Holzheu T., \& Laster D. (2010). The Impact of Inflation on Insurers. Sigma No 4.

Mankiw, G. (2005). Pengantar Ekonomi Makro. Jakarta (ID), Salemba Empat.

[Menkeu] Menteri Keuangan. (2010). Peraturan Menteri Keuangan Nomor 18 Tahun 2010 tentang Penerapan Prinsip Dasar Penyelenggaraan Usaha Asuransi dan Usaha Reasuransi dengan Prinsip Syariah. 
[Menkeu] Menteri Keuangan. (2011). Peraturan Menteri Keuangan Nomor 10 Tahun 2011 tentang Kesehatan Keuangan Usaha Asuransi dan Usaha Reasuransi dengan Prinsip Syariah.

[OJK] Otoritas Jasa Keuangan. (2016). Peraturan OJK Nomor 71 Tahun 2016 tentang Kesehatan Keuangan Perusahaan Asuransi dan Perusahaan Reasuransi dengan Prinsip Syariah [Internet]. [diakses 2020 Agustus 9]. Tersedia pada: http://www.ojk.go.id.

[OJK] Otoritas Jasa Keuangan. (2019). Survei Nasional Literasi dan Inklusi Keuangan [Internet]. [diakses pada 2020 Desember 29]. Tersedia pada: http://www.ojk.go.id.

Prasetyantoko A. \& Parmono R. (2015). Does firm size matter? An empirical study of firm performance in Indonesia. Jurnal Manajemen Bisnis, 2(2), 87-97.

Ramdhani, M.F. (2019). Factors that influence surplus underwriting of tabarru funds in general Islamic insurance companies. The 2nd International Conference on Islamic Economics, Business, and Philanthropy, 3(2), 249-364.

[RI] Republik Indonesia. (2014). Undang-Undang Republik Indonesia Nomor 40 Tahun 2014 tentang Peransuransian.

Sastri I.A.I.P., Sujana E. \& Sinarwati N.K. (2017). Pengaruh pendapatan premi, hasil underwriting, hasil investasi dan risk based capital terhadap laba perusahaan asuransi (studi empiris pada perusahaan asuransi yang terdaftar di BEI periode 2011-2015). e-journal S1 Akuntansi Universitas Ganesha, 7(1).

Zein F.D. \& Shofawati A. (2017). Kondisi makro ekonomi terhadap hasil investasi asuransi jiwa syariah di Indonesia. Jurnal Ekonomi Syariah Teori dan Terapan, 5(10), 773-786. 